\title{
LANGUAGE LEARNING STRATEGIES AND EXTRAVERSION/INTROVERSION IN THE EFL CONTEXT
}

ABSTRACT. Due to the fact that extraverted and introverted personalities behave and react rather differently, especially in the context of foreign language learning, teachers and learners often believe that these two personality types have different learning habits and require different learning environments. This is often reflected in different choices of language learning strategies that these two personality types make, which has already been proven in several research studies. However, these studies did not investigate the selection of language learning strategies in connection to extraversion/ introversion among high school students, so this paper aims to determine any possible links for this age group. In order to do that the research relies on the EPQR-S to determine the students' personality type and Strategy Inventory for Language Learning to determine the participants' strategy preference. The participants who took part in this research were sixty firstand second-grade students aged 15 to 17 from a medical high school in Novi Sad. The results from this research were analyzed quantitatively and, based on the results, it can be concluded that there are differences in strategy selection. Extraverts use compensation strategies most frequently, while affective strategies are reported to be the least frequently used. Introverts,

1 radic.bojanic@ff.uns.ac.rs, radic.bojanic@gmail.com

The paper is the result of research conducted within project no. 01600 funded by the Ministry of Education, Science, and Technological Development of the Republic of Serbia.

This paper was submitted on November $24^{\text {th }}, 2020$ and accepted for publication at the meeting of the Editorial Board held on March $24^{\text {th }}, 2021$. 
on the other hand, report the highest use for metacognitive strategies and the lowest for affective strategies, similar to extraverts.

KEYWORDS: extraversion; introversion; EFL; language learning strategies; high school students.

INTRODUCTION

Many research studies so far have established that foreign language learning is best regulated by language learning strategies (henceforth LLS), which are effective, purposeful and directed attempts of the learner to consciously apply different techniques, methods and approaches in order to learn the foreign language (cf. Oxford, 1990; Dörnyei, 2005, p. 165). The selection of LLS is influenced by a variety of factors, some tied to the learning context and others stemming from the learner's personality. The latter is a complex phenomenon whose many traits can greatly contribute to success in foreign language learning, but can also impede it. In English language teaching (ELT) educational studies the greatest emphasis has been put on the dimension of extraversion/introversion since the behaviour of these personality types is best seen in communication, which is crucial for success in foreign language acquisition. This paper relies on the quantitative approach to investigate how the factor of extraversion and introversion influences the selection of LLS. The research includes sixty high school students from Serbia who filled in the Eysenck Personality Questionnaire - Revised Short Form - Extraversion and Strategy Inventory for Language Learning and it aims to find some regularities which will shape pedagogical implications and recommendations in order to improve the process of foreign language acquisition.

\section{THEORETICAL FRAMEWORK}

Language learning strategies are one of the most important concepts in the field of foreign language learning and in the period of the last few decades they have been vastly researched. Chamot (1987, p. 71) defines them as "processes, techniques, approaches and actions that students take to facilitate the learning and recall of both linguistic and content areas of information" but researchers such as Rubin (1975), O'Malley and Chamot (1990), Oxford (1990), Ellis (1994) and Williams and Burden (2001) have also determined that LLS are learning processes consciously selected by the learner 
which can facilitate the internalization, storage, retrieval, or use of the new language (Oxford, 1990, p. 4; Cohen, 1998, p. 5). Chen (2016, p. 4) stipulates that LLS help learners in a number of ways because students are able to identify the material that needs to be learned (e.g. make a distinction between familiar and new words), distinguish it from other material if need be (e.g. decide if a new word should be learnt or not at that point in the learning process), group it for easier learning (e.g., grouping vocabulary by category into nouns, verbs, adjectives, adverbs etc.), have repeated contact with the material (e.g. through classroom tasks or homework assignments), and formally commit the material to memory when it does not seem to be acquired naturally (whether through rote memory techniques such as repetition, the use of mnemonics, or some other memory technique).

Various authors such as Rubin (1975), O'Malley and Chamot (1990) and Oxford (1990) classified LLS in various ways, but the taxonomy used in this paper is the one by Oxford (1990), where she divides LLS into direct (directly involve the target language) and indirect strategies (tackling the learning context, not the learning process itself). The former group of strategies is further divided into memory strategies (creating mental linkages, applying images and sounds, reviewing well, employing action), cognitive strategies (practicing, receiving and sending messages, analyzing and reasoning, creating structure for input and output) and compensation strategies (guessing intelligently, overcoming limitations in speaking and writing), while the latter tackles the factors that surround the process of learning (metacognition, social contacts and students' affective states).

The very process of selection of LLS is influenced by a host of factors: the nature of the task determines the scope and possible combination of LLS (Oxford, 1990, p. 13), students' motivation influences the number and appropriateness of LLS (Cohen, 2003) and foreign language proficiency also has a similar effect on LLS (Pavičić Takač, 2008, p. 55; Crnogorac Stanišljević, 2018, p. 259). In addition, Catalan (2003) and Bikicki (2012) stipulate that the students' gender is also significant when LLS are concerned claiming that female students use a wider range of strategies in comparison to male students. Furthermore, Brown (2000, pp. 11-12) claims that the student's learning style has a powerful effect on the choice of LLS, so for example, students with the dominant analytical learning style will prefer cognitive strategies of analysis, deductive reasoning or translation (cf. 
Komaromi 2012). Finally, Ehrman and Oxford (1989) investigated the connection of LLS and learner personality including extraversion/introversion and found that introverts and extraverts require different learning environments due to their different personalities.

Nelson-Jones (2015, p. 65) defines extraversion as "an attitude type characterized by concentration of interest on the external objects" i.e. the focus is on the outer world and introversion as "an attitude type characterized by orientation in life that particularly values subjective psychic contents"(Nelson-Jones, 2015, p. 65), i.e. the focus is on one's inner mental activity. According to Nelson-Jones (2015), extraverts are talkative, assertive, gregarious, impulsive and enthusiastic, they like being around other people and taking part in activities which involve socializing, while introverts are quiet, careful, thoughtful and reserved and they prefer being on their own rather than around other people. Eysenck and Chan (1982) also came to the similar findings, i.e. that extraverts receive energy from outside sources, whereas introverts thrive on the inner world of ideas. It can be, therefore, inferred that introverts and extraverts prefer different activities and learning environments and, therefore, they may prefer different language learning strategies, which was also pointed out by Ehrman and Oxford (1989). They supported this by stating that extraverts, for example, prefer highly interactive activities such as group work or role-play, whereas introverts prefer working alone or in pairs with someone they know very well and dislike group work. Therefore, they conducted several studies to investigate the type of LLS these two personality types use in the learning process.

In their first study, Ehrman and Oxford (1989) hypothesized that extraverted learners use more affective and social strategies and authentic language and that introverted learners use more independent and self-management strategies. The only significant difference which was established in this study was related to affective strategies, which were used more by extraverts. In addition, extraverted learners reported using visual strategies more than introverts. In contrast to the researchers' expectations, the study showed that introvert learners tend to use more strategies for searching for and communicating meaning than extraverted learners. Based on these results, the authors concluded that introverts have a tendency to try looking for the context and meaning before they start acting, which could be associated with their personality characteristics. 
In their second study, Ehrman and Oxford (1990) found a significant difference in terms of social and metacognitive strategies, the first more selected by extraverts and the second one by introverts. In addition, introverts stated that they prefer studying alone and avoid social contact, which can also be associated with their preference for reading and writing skills. However, the study did not show any differences between introverts and extraverts in terms of memory strategy use, which can be supported by the fact that introverts do well in long-term and extraverts in short-term memory. Most of the results from the first two studies were confirmed in Oxford and Ehrman (1995).

Wakamoto's (2000) research including 254 college students showed extraverted learners' preference for functional practice and social affective strategies. He found that extraverts tend to use eight LLS more than introverts, but no significant differences were found for metacognitive strategies. Lastly, Nikoopour and Farsani (2010) conducted a study which included 137 students from five different universities and found that these two personality types did not show any significant difference regarding the choice of language learning strategies.

Varied results of these studies can be explained by the fact that factors other than learners' personality should be taken into consideration, i.e. all these studies included learners of different ages, cultural backgrounds and different levels of proficiency. None of them, however, used a sample of high school students, who are a population of specific psychological and emotional characteristics due to the fact that they are undergoing puberty and maturation, which is why they are the focus group in this paper.

METHOD

In order to confirm the results from earlier studies which claim that the dimension of extraversion/introversion influences the choice of LLS in the EFL (English as a Foreign Language) context, we decided to research a sample of sixty teenagers who attend the first and second grades of medical high school in Novi Sad (thirty students from each grade). They were between 15 and 17 years of age so their parents signed a consent form for this research study. As for their proficiency level in English, they have been learning English since the first grade of primary school, so on average they were the B1 level of CEFR, but the expectation is that, due to factors that affect profi- 
ciency, it would vary to some extent. For the purpose of this research, the participants were asked to fill in the Eysenck Personality Questionnaire - Revised Short Form - Extraversion (EPQR-S) (Eysenck and Eysenck, 1985), which is part of a larger inventory of personality traits and contains 12 items for the subscale of extraversion, and Oxford's (1990) Strategy Inventory for Language Learning, which comprises 50 statements that informants assess on a five-point Likert scale. Each item in both questionnaires was translated into Serbian so that the participants could answer more accurately. On the basis of their answers in the first questionnaire the participants were categorized either as extraverts or introverts and then these results were intersected with the data from the second questionnaire in order to compare the strategy selection of extraverts and introverts.

\section{RESULTS AND DISCUSSION}

As previously mentioned, the participants were asked to complete the Eysenck Personality Questionnaire - Revised Short Form (dimension of extraversion) in order to determine which personality type they belong to and on the basis of their answers it was established that the sample consists of more extraverts than introverts (Table 1).

\begin{tabular}{|c|c|c|}
\hline & EXTRAVERTS & INTROVERTS \\
\hline $1^{\text {ST GRADE }}$ & 24 & 6 \\
\hline $2^{\text {ND }}$ GRADE & 22 & 8 \\
\hline TOTAL & 46 & 14 \\
\hline \hline
\end{tabular}

TABLE 1: NUMBER OF EXTRAVERTS AND INTROVERTS IN THE SAMPLE

Before comparing the frequency of the use of LLS by extraverts and introverts we should note that all participants together showed moderate strategy use (overall M=2.87) according to Oxford's (1990) classification (low: 1.00-2.4, medium: 2.5-3.4, high: 3.5-5). However, the average use of separate strategies varied greatly. Namely, the least used strategy had a low use $(M=1.28)$, while the most used strategy had a high use $(M=4.17)$, which definitely warrants further investigation with respect to the personality dimension of extraversion/introversion in relation to the choice of LLS. 
When the average use of LLS for both extraverted and introverted students is compared (Table 2), we can see that extraverts use compensation strategies most frequently $(\mathrm{M}=3.25)$, while affective strategies are reported to be the least frequently used $(M=2.55)$. Introverts, on the other hand, report the highest use for metacognitive strategies $(\mathrm{M}=3.12)$ and the lowest for affective strategies $(\mathrm{M}=2.11)$, similar to extraverts.

\begin{tabular}{|l|r|r|r|r|}
\hline & \multicolumn{2}{|c|}{ extraverts } & \multicolumn{2}{c|}{ introverts } \\
\hline LLS category & $\mathrm{M}$ & \multicolumn{1}{|c|}{ SD } & $\mathrm{M}$ & \multicolumn{1}{c|}{ SD } \\
\hline Memory strategies & 2.56 & 0.6084 & 2.13 & 0.4789 \\
\hline Cognitive strategies & 3.05 & 0.5649 & 2.60 & 0.5299 \\
\hline Compensation strategies & 3.25 & 0.3709 & 2.96 & 0.5360 \\
\hline Metacognitive strategies & 3.15 & 0.5226 & 3.12 & 0.4432 \\
\hline Social strategies & 3.11 & 0.5071 & 2.69 & 0.6238 \\
\hline Affective strategies & 2.55 & 0.9260 & 2.11 & 0.7502 \\
\hline average & 2.95 & 0.5833 & 2.60 & 0.5603 \\
\hline \hline
\end{tabular}

TABLE 2: FREQUENCY OF LLS CATEGORY USE

When individual strategies are observed, there are some differences between extraverts and introverts, which will be discussed in the rest of the paper. The first observed group of strategies are memory strategies (Table 3), where no high LLS use was reported for either extraverts or introverts. Strategies 5, 6, 7 and 8 have a low use, which is expected to some extent, as the informants are teenagers who usually do not learn the foreign language this way. The only point of difference between extraverts and introverts in this group of LLS is strategy 9, which corroborates the finding of Ehrman and Oxford (1989) that extraverts are more often visual learners.

\begin{tabular}{|l|r|r|}
\hline \multicolumn{1}{|c|}{ MEMORY STRATEGY } & \multicolumn{1}{|c|}{$\begin{array}{c}\text { M } \\
\text { EXTRAVERTS }\end{array}$} & \multicolumn{1}{|c|}{$\begin{array}{c}\text { M } \\
\text { INTROVERTS }\end{array}$} \\
\hline $\begin{array}{l}\text { 1. I think of relationships between what I already know and } \\
\text { new things I learn in English. }\end{array}$ & 2.98 & 2.43 \\
\hline $\begin{array}{l}\text { 2. I use new English words in a sentence so I can remember } \\
\text { them. }\end{array}$ & 2.98 & 2.29 \\
\hline \hline
\end{tabular}

TABLE 3: COMPARATIVE FREQUENCY OF MEMORY STRATEGIES 


\begin{tabular}{|c|c|c|}
\hline $\begin{array}{l}\text { 3. I connect the sound of a new English word and an image or } \\
\text { the picture of the word to help me remember the word. }\end{array}$ & 3.28 & 2.50 \\
\hline $\begin{array}{l}\text { 4. I remember a new English word by making a mental } \\
\text { picture of a situation in which the word might be used. }\end{array}$ & 3.22 & 2.57 \\
\hline 5. I use rhymes to remember new English words. & 2.26 & 2.14 \\
\hline 6. I use flashcards to remember new English words. & 1.70 & 1.21 \\
\hline 7. I physically act out new English words. & 1.78 & 1.43 \\
\hline 8. I review English lessons often. & 2.13 & 2.36 \\
\hline $\begin{array}{l}\text { 9. I remember new English words or phrases by } \\
\text { remembering their location on the page, on the board, or on } \\
\text { a street sign. }\end{array}$ & 2.74 & 2.21 \\
\hline
\end{tabular}

TABLE 3: COMPARATIVE FREQUENCY OF MEMORY STRATEGIES

The second group of LLS, cognitive strategies, again show medium use in more than half of strategies for both extraverts and introverts, but there are also some interesting differences. Namely, strategy 11 indicates a high use for extraverts and medium use for introverts, which is in line with extraverts' preference for talking and communication. Another point of difference between the two personality types is strategy 22 , which testifies of extraverts' fluency and spontaneity in the use of the foreign language. Additionally interesting is the high use for strategy 15 for both personality types, but having in mind the profile of the informants in this study, it can be concluded that this is regular teenage behaviour (Radić-Bojanić, 2021). Finally, two strategies that show a low use for both personality types, 17 and 20, indicate that the informants rarely write in English and that they do not try to find patterns in English, which could be connected with the syllabus in the medical high school.

\begin{tabular}{|l|r|r|}
\hline \multicolumn{1}{|c|}{ COGNITIVE STRATEGY } & $\begin{array}{c}\text { M } \\
\text { EXTRAVERTS }\end{array}$ & $\begin{array}{c}\text { M } \\
\text { INTROVERTS }\end{array}$ \\
\hline 10. I say or write new English words several times. & 3.35 & 3.07 \\
\hline 11. I try to talk like native English speakers. & $\underline{3.57}$ & 2.86 \\
\hline
\end{tabular}

TABLE 4: COMPARATIVE FREQUENCY OF COGNITIVE STRATEGIES 


\begin{tabular}{|l|r|r|}
\hline 12. I practice the sounds of English. & 2.96 & 2.50 \\
\hline 13. I use the English words I know in different ways. & 2.39 & 2.86 \\
\hline 14. I start conversations in English. & $\underline{4.28}$ & 2.21 \\
\hline $\begin{array}{l}\text { 15. I watch English language TV shows spoken in English } \\
\text { or go to movies spoken in English. }\end{array}$ & 2.59 & 2.64 \\
\hline $\begin{array}{l}\text { 16. I read for pleasure in English. } \\
\text { 17. I write notes, messages, letters, or reports in English. }\end{array}$ & 2.33 & 2.21 \\
\hline $\begin{array}{l}\text { 18. I first skim read an English passage (read over the } \\
\text { passage quickly) then go back and read carefully. }\end{array}$ & 3.26 & 2.57 \\
\hline $\begin{array}{l}\text { 19. I look for words in my own language that are similar to } \\
\text { new words in English. }\end{array}$ & 2.78 & 2.50 \\
\hline $\begin{array}{l}\text { 20. I try to find patterns in English. } \\
\text { 21. I find the meaning of an English word by dividing it } \\
\text { into parts that I understand. }\end{array}$ & 2.28 & 2.93 \\
\hline $\begin{array}{l}\text { 22. I try not to translate word for word. } \\
\text { in English. }\end{array}$ & 3.54 & 2.50 \\
\hline \hline
\end{tabular}

TABLE 4: COMPARATIVE FREQUENCY OF COGNITIVE STRATEGIES

The last group of direct LLS, compensation strategies, again shows a medium use in the majority of cases, but there are some notable differences. In strategy 24 extraverts register a medium use, while introverts report a high use. This difference could be explained by the fact that this strategy requires some consideration of the context in order to make guesses, which is the behaviour more typical of introverts, who usually first think and then act as Ehrman and Oxford (1989) also concluded. On the other hand, strategy 26, which indicates a high use for extraverts and a medium use for introverts, requires the opposite type of behaviour and spontaneity, which is more typical of extraverts. Finally, strategy 29 is the only one where both introverts and extraverts report a high use. However, this strategy is not inherently tied to personality types, instead it 
testifies of the level of the informants' proficiency, i.e. their knowledge of synonyms.

\begin{tabular}{|l|r|r|}
\hline \multicolumn{1}{|c|}{ COMPENSATION STRATEGY } & \multicolumn{1}{|c|}{$\begin{array}{r}\text { M } \\
\text { EXTRAVERTS }\end{array}$} & \multicolumn{1}{|c|}{$\begin{array}{r}\text { M } \\
\text { INTROVERTS }\end{array}$} \\
\hline $\begin{array}{l}\text { 24. To understand unfamiliar English words I make } \\
\text { guesses. }\end{array}$ & 3.33 & 3.50 \\
\hline $\begin{array}{l}\text { 25. When I can't think of a word during a conversation in } \\
\text { English, I use gestures. }\end{array}$ & 3.30 & 2.93 \\
\hline $\begin{array}{l}\text { 26. I make up new words if I do not know the right ones in } \\
\text { English. }\end{array}$ & 3.28 \\
\hline $\begin{array}{l}\text { 27. I read English without looking up every new word. } \\
\begin{array}{l}\text { 28. I try to guess what the other person will say next in } \\
\text { English. }\end{array}\end{array}$ & 3.46 \\
\hline $\begin{array}{l}\text { 29. If I can't think of an English word, I use a word or phrase } \\
\text { that means the same thing. }\end{array}$ & 3.63 \\
\hline \hline
\end{tabular}

TABLE 5: COMPARATIVE FREQUENCY OF COMPENSATION STRATEGIES

The first in the group of indirect LLS are metacognitive strategies, where again the majority of strategies have a reported medium use. Strategy 32 shows a high use for both subsamples, which is commendable, while strategy 34 shows a low use for both subsamples. The only point of difference is strategy 33, where extraverts actively seek out new ways to be better learners, which is a behaviour more typical of this personality type and also something that Ehrman and Oxford (1990) established.

\begin{tabular}{|l|r|r|}
\hline \multicolumn{1}{|c|}{ METACOGNITIVE STRATEGy } & \multicolumn{1}{c|}{$\begin{array}{c}\text { M } \\
\text { EXTRAVERTS }\end{array}$} & \multicolumn{1}{c|}{$\begin{array}{c}\text { M } \\
\text { INTROVERTS }\end{array}$} \\
\hline 30. I try to find as many ways as I can to use my English. & 3.30 & 3.29 \\
\hline $\begin{array}{l}\text { 31. I notice my English mistakes and use that } \\
\text { information to help me do better. }\end{array}$ & 3.35 & 3.21 \\
\hline 32. I pay attention when someone is speaking English. & $\underline{3.83}$ & 3.93 \\
\hline
\end{tabular}

TABLE 6: COMPARATIVE FREQUENCY OF METACOGNITIVE STRATEGIES 


\begin{tabular}{|l|r|r|}
\hline 33. I try to find out how to be a better learner of English. & $\underline{3.65}$ & 3.36 \\
\hline $\begin{array}{l}\text { 34. I plan my schedule so I will have enough time to study } \\
\text { English. }\end{array}$ & 2.13 & 2.36 \\
\hline 35. I look for people I can talk to in English. & 2.91 & 3.14 \\
\hline $\begin{array}{l}\text { 36. I look for opportunities to read as much as possible in } \\
\text { English. }\end{array}$ & 2.70 & 2.64 \\
\hline 37. I have clear goals for improving my English skills. & 3.02 & 3.00 \\
\hline 38. I think about my progress in learning English. & 3.46 & 3.14 \\
\hline \hline
\end{tabular}

TABLE 6: COMPARATIVE FREQUENCY OF METACOGNITIVE STRATEGIES

When affective LLS are concerned, two strategies show a medium use for both personality types ( 39 and 40 ) and two strategies show a very low use (43 and 44), which indicates that neither introverts nor extraverts think about or discuss their feelings regarding foreign language learning. As for strategies 41 and 42 , in both cases extraverts report a higher use, which indicates that introverts neither encourage themselves nor do they regulate their negative feelings to a large extent. A similar low use of affective strategies by introverts was also discovered by Ehrman and Oxford (1989) and Oxford and Ehrman (1995).

\begin{tabular}{|l|r|r|}
\hline \multicolumn{1}{|c|}{ AfFECTIVE STRATEGY } & \multicolumn{1}{|c|}{$\begin{array}{c}\text { M } \\
\text { EXTRAVERTS }\end{array}$} & $\begin{array}{c}\text { M } \\
\text { INTROVERTS }\end{array}$ \\
\hline 39. I try to relax whenever I feel afraid of using English. & 3.43 & 2.71 \\
\hline $\begin{array}{l}\text { 40. I encourage myself to speak English even if I am afraid } \\
\text { of making a mistake. }\end{array}$ & 3.37 & 2.00 \\
\hline $\begin{array}{l}\text { 41. I give myself a reward or treat when I do well in English. } \\
\text { using English. }\end{array}$ & 2.78 & 2.21 \\
\hline
\end{tabular}

TABLE 7: COMPARATIVE FREQUENCY OF AFFECTIVE STRATEGIES 


\begin{tabular}{|l|r|r|}
\hline 43. I write down my feelings in a language learning diary. & $\mathbf{1 . 3 3}$ & $\mathbf{1 . 1 4}$ \\
\hline $\begin{array}{l}\text { 44. I talk to someone else about how I feel when I am } \\
\text { learning English. }\end{array}$ & $\mathbf{1 . 4 8}$ & $\mathbf{1 . 2 9}$ \\
\hline
\end{tabular}

TABLE 7: COMPARATIVE FREQUENCY OF AFFECTIVE STRATEGIES

The last group of LLS are social strategies, where, despite expectations, both extraverts and introverts report a medium use, except for strategy 50, where a low use is registered. This indicates that neither extraverts nor introverts are interested in Anglophone culture, which is not an issue that concerns personality types, but a higher level of ethnocentrism (Radić-Bojanić, 2019). The only point of difference is strategy 45 , where extraverts report a high use and introverts a medium use, which falls in line with typical behaviour of extraverted students, as also confirmed by Ehrman and Oxford (1990) and Wakamoto (2000).

\begin{tabular}{|c|c|c|}
\hline SOCIAL STRATEGY & $\begin{array}{c}\mathrm{M} \\
\text { EXTRAVERTS }\end{array}$ & $\begin{array}{c}\mathrm{M} \\
\text { INTROVERTS }\end{array}$ \\
\hline $\begin{array}{l}\text { 45. If I do not understand something in English, I ask the } \\
\text { other person to slow down or say it again. }\end{array}$ & $\underline{3.63}$ & 3.36 \\
\hline 46. I ask English speakers to correct me when I talk. & 3.37 & 2.86 \\
\hline 47. I practice English with other students. & 3.00 & 2.86 \\
\hline 48. I ask for help from English speakers. & 3.41 & 2.86 \\
\hline 49. I ask questions in English. & 3.02 & 2.71 \\
\hline 50. I try to learn about the culture of English speakers. & 2.20 & 1.50 \\
\hline
\end{tabular}

TABLE 8: COMPARATIVE FREQUENCY OF SOCIAL STRATEGIES

On the basis of the results presented above it can be concluded that the present research study confirmed to a great extent what authors like Ehrman and Oxford $(1989,1990)$, Oxford and Ehrman (1995), Wakamoto (2000) etc. found concerning the connection of LLS and the personality dimension of extraversion/introversion. Since the sample in the research were teenagers, it might be advisa- 
ble to suggest some options that would cater for both personality types while at the same time developing their strategic competence.

The first suggestion is to raise students' awareness concerning the range of LLS and their appropriateness to the given task or language skill. In addition to raising awareness, teachers should actively practice LLS use with their students and help them decide which strategies work best for their own personality and learning style. In other words, students should know that they have a choice; various options to do the task and participate in the process of language learning and that none of the choices are better or worse than others. This will make students understand that learning is inherently tied to their own personality and they should, therefore, listen to the inner self which will help them gravitate towards the best individual choices.

In addition to raising students' awareness, it is important to raise teachers' awareness as well, because they should know that student participation is not only tied to verbal expression in class, but also to other activities that agree much more with introverts such as quiet pair-work, helping others, attentive listening and diligent note-taking. There is much value in such student behaviour and teachers should find ways to reward it and give praise to such students, which will be a recognition of their hard work and a reinforcement for future actions. Furthermore, due to introverts' nature, they might need more time to answer a question so teachers should be more patient and understanding in this case, as they should also find ways to "tone down" extravert students, whose outgoing nature might lead them to dominate the classroom.

Finally, activities in class should vary so both extraverts and introverts have the opportunity to test and try out different LLS in order to see what works best for them. This might be best achieved by a flow and exchange of social and reflective activities, where more dynamic group work is followed by individual or pair-work activities. This actually means that both personality types get to experience their comfort zones, but also spaces beyond them, which will in time make them more flexible, but also gradually reduce anxiety, especially in the case of introverts who usually struggle in louder, group activities and public speaking.

CONCLUSION

When comparing the results of extraverts and introverts, both differences and similarities could be noticed. First of all, in the comparison of the six groups of LLS the only difference between the two 
personality types was in the case of two most used categories. Namely, extraverts reported compensation strategies to be the most used category followed by metacognitive strategies, whereas introverts stated it was the other way around. The remaining four categories were ranked in the same way in both cases -social, cognitive, memory and affective strategies. Another aspect taken into consideration when comparing two personality types was the average use of the groups of LLS. When it comes to the average use of each category, extraverts once again showed a higher use of strategies: extraverts' average LLS use was $M=2.95$, whereas introverts reported the slightly lower use of $M=2.60$. More specifically, in the case of extraverted participants, all six categories had moderate use. On the other hand, introverts reported using only four of the categories moderately, whereas the other two had a low LLS use. Furthermore, by comparing the lowest and the highest means of individual LLS, certain differences between extraverted and introverted participants are also noticeable. Namely, the least frequently used strategy reported by extraverts had a low use $(\mathrm{M}=1.33$, I write down my feelings in a language learning diary), while the most frequently used strategy had a high use ( $\mathrm{M}=4.28$, I watch English language TV shows spoken in English or go to movies spoken in English). Similarly, for introverted students the least frequently used strategy had a rather low frequency ( $\mathrm{M}=1.14$, I write down my feelings in a language learning diary), whereas the most frequently used strategy had a high use $(M=3.93$, I pay attention when someone is speaking English). All of this shows that extraverts are more likely to include strategies into their language learning process, which is also something that Wakamoto (2000) found. Since personality traits are not prone to changes (Dörnyei, 2005), it is therefore advisable that teachers vary the teaching methods and approaches so as to suit both personality types and to apply a range of assessment methods in order to accommodate for both personality types. vokabulara. In: B. Radić-Bojanić (Ed.), Strategije i stilovi u nastavi engleskogjezika (11-25). Novi Sad: Filozofski fakultet.

Brown, D. H. (2000). Teaching by Principles: An Interactive Approach to Language Pedagogy. New York: Longman.

Catalan, R. M.J. (2003). Sex differences in L2 vocabulary learning strategies. International Journal of Applied Linguistics, 13 (1), 54-77. doi:10.1111/1473-41 92.00037 
Chamot, A. U. (1987). The power of learning strategies. Ohio Bilingual-Multicultural Update, 4, 6-11.

Chen, Z. J. (2016). Language learning strategies based on the educational concept of innovation and entrepreneurship. Open Access Library Journal, 3, e2780. http://dx.doi.org/10.4236/oalib.1102780

Cohen, A. D. (1998). Strategies in Learning and Using a Second Language. Harlow: Essex, Longman.

Cohen, A. (2003). The learner's side of foreign language learning: Where do styles, strategies, and tasks meet? International Review of Applied Linguistics, 41, 279-291.

Crnogorac Stanišljević, B. (2018). Kompenzatorne strategije u razvijanju jezičke veštine slušanja u nastavi engleskog jezika - kvalitativno istraživanje. Metodički vidici, 9, 249-264. doi:10.19090/mv.2018.9.249-264

Dörnyei, Z. (2005). The Psychology of the Language Learner: Individual Differences in Second Language Acquisition. Mahwah, NJ: Lawrence Erlbaum.

Ehrman, M. and Oxford, R. (1989). Effects of sex differences, career choice, and psychological type on adult language learning strategies. Modern Language Journal, 73 (1), 1-13.

Ehrman, M. and Oxford, R. (1990). Adult language learning styles and strategies in an intensive training setting. Modern Language Journal, 74, 311-326.

Ellis, R. (1994). The Study of Second Language Acquisition. Oxford: Oxford University Press.

Eysenck, S. and Chan. (1982). A comparative study of personality in adults and children: Hong Kong vs. England. Personality and Individual Differences, 3(2), 153-160.

Eysenck, H. J. and Eysenck, M. W. (1985). Personality and Individual Differences. New York: Plenum.

Komaromi, B. (2012). Ocena uspešnosti prilagođavanja nastave različitim stilovima učenja. In: B. Radić-Bojanić (Ed.), Strategije i stilovi u nastavi engleskogjezika (103-114). Novi Sad: Filozofski fakultet.

Nelson-Jones, R. (2015). Nelson-Jones' Theory and Practice of Counselling and Psychotherapy. Los Angeles: Sage Publications.

Nikoopour, J. and Farsani, M. A. (2010). On the relationship between language learning strategies and personality types among Iranian EFL learners. Journal of English Studies, 1 (1), 81-101.

O'Malley, M. J. and Chamot, A. U. (1990). Learning Strategies in Second Language Acquisition. Cambridge: Cambridge University Press.

Oxford, R. (1990). Language Learning Strategies: What Every Teacher Should Know. New York: Newbury House/Harper \& Row. 
Oxford, R. L. and Ehrman, M. E. (1995). Adults' language learning strategies in an intensive foreign language program in the United State. System, 23 (3), 359-386.

Pavičić Takač, V. (2008). Vocabulary Learning and Foreign Language Acquisition. Clevedon: Multilingual Matters.

Radić-Bojanić, B. (2019). Etnocentrizam i studije stranih jezika u Srbiji. Nasleđe, 44, 139-152.

Radić-Bojanić, B. (2021). Audiovisual media and the acquisition of EFL vocabulary. Nasleđe [in press].

Rubin, J. (1975). What the "good language learner" can teach us. TESOL Quarterly, 9, 41-51.

Wakamoto, N. (2000). Language learning strategy and personality variables: Focusing on extraversion and introversion. International Review of Applied Linguistics in Language Teaching, 38 (1), 71-81.

Williams, M. and Burden, R. L. (2001). Psychology for Language Teachers. Cambridge: Cambridge University Press.

БИЉАНА Б. РАДИЋ-БОЈАНИЋ

УНИВЕРЗИТЕТ У НОВОМ САДУ

ФИЛОЗОФСКИ ФАКУЛТЕТ

ОДСЕК ЗА АНГЛИСТИКУ

РЕЗИМЕ

СТРАТЕГИЈЕ ЗА УЧЕЊЕ ЈЕЗИКА И ЕКСТРАВЕРЗИЈА/ИНТРОВЕРЗИЈА У КОНТЕКСТУ НАСТАВЕ ЕНГЛЕСКОГ ЈЕЗИКА КАО СТРАНОГ

Пошто се екстравертне и интровертне личности понашају и реагују различито у многим ситуацијама, што укључује и наставу страних језика, и наставници и ученици верују да ова два типа личности имају различите навике у учењу и стога су им потребне другачије околности да би могли да напредују. Више истраживања утврдило је да екстравертни ученици више воле групне активности, јавно говорење, спонтано учешће у задацима, те да им такве активности не изазивају анксиозност. С друге стране, установљено је да интровертни ученици преферирају индивидуалне активности током којих имају времена да размисле и да припреме одговор, као и да се не осећају нарочито пријатно кад морају да говоре пред свима, поготово без претходне припреме. Међутим, у контексту наставе страних језика веома је значајно и испитати како се ова два типа личности 
односе према стратегијама за учење језика, тачније који тип личности чешће користи које врсте стратегија, да би се на основу резултата могле дати педагошке препоруке за развој стратешке компетенције сходно ономе што се установи за сваки тип личности. Стога се у овом раду испитује група од 60 средњошколаца да би се утврдило које стратегије чешће користе екстраверти, а које интроверти. Подаци су прикупљени уз помоћ два инструмента: Ајзенков кратки упитник за тип личности димензија екстраверзије и Инвентар стратегија за учење језика. Док је први упитник дао податке о томе коме типу личности испитаници припадају, други је одредио стратешке преференције. Квантитативна анализа резултата је утврдила да екстравертни ученици најчешће користе компензаторне стратегије, док интроверти најчешће користе метакогнитивне стратегије, а обе групе најмање користе афективне стратегије. С обзиром на то да су у питању тинејџери, ниска или висока употреба неких стратегија није изненађујућа: овај узраст преферира да учи страни језик кроз аудиовизуелне медије, док с друге стране ретко користе стратегије које подразумевају покрете тела, цртање, прављење модела или мапа. На основу добијених резултата у раду се износе и предлози за развој стратешке компетенције код оба типа личности: подизање свести о постојању стратегија код ученика; подизање свести о различитим типовима личности код наставника; рад на развоју и употреби стратегија; смењивање различитих врста стратегија које више одговарају једном или другом типу личности са циљем да оба постану флексибилнија и испробају начине рада и учења које до тада нису пробали. Ово ће свим ученицима проширити репертоар стратегија и помоћи им да са више успеха савладају страни језик.

КљУчнЕ РЕчи: екстраверзија; интроверзија; енглески језик као страни; стратегије за учење језика; средњошколци.

Овај чланак је објављен и дистрибуира се под лиценцом Creative Commons Ауторство-Некомерцијално Међународна 4.0 (CC BY-NC 4.0 |

https://creativecommons.org/licenses/by-nc/4.0/).

This paper is published and distributed under the terms and conditions of the Creative Commons Attribution-NonCommercial International 4.0 licence (CC BY-NC 4.0 | https://creativecommons.org/licenses/by-nc/4.0/). 